\title{
MENINGKATKAN KEMAMPUAN SISWA DALAM MENULIS SASTRA PUISI DENGAN MENGGUNAKAN MODEL INKUIRI DAN LATIHAN BIMBINGAN
}

\author{
Dindin M. Z. M \\ Universitas Pasundan Bandung \\ dindinmzm@unpas.ac.id
}

\begin{abstract}
The string of words in poetry is a literary work that has a hermeneutic meaning with a broad interpretation or interpretation. Even as the process changes from something ignorance to understanding. This research aims to explain the learning process of students' ability to write literary works of poetry with inkuiri techniques. The methods used by class actions in cycles 1 and 2 are through planning, action, observation, and reflection, while the instruments required are test and nontest, data analysis techniques using quantitative and qualitative. The results showed that the ability of students to write poetry literary works using inkuiri techniques, training and guidance in grade VIII-A students of SMPN 1 Rancabali, Alamendah, Kecamatan Rancabali, Bandung Regency, in cycles 1 and 2 experienced improved learning and changed students' behavior towards significant writing interests.
\end{abstract}

Keywords; writing poetry, inkuiri, and guidance training

Abstrak - Untaian kata dalam puisi merupakan karya sastra yang mempunyai makna hermeneutik dengan penafsiran atau interpretasi yang luas. Bahkan sebagai proses perubahan dari sesuatu ketidaktahuan menjadi mengerti. Penelitian ini bertujuan menjelaskan proses pembelajaran kemampuan siswa dalam menulis karya sastra puisi dengan teknik inkuiri. Metode yang digunakan tindakan kelas pada siklus 1 dan 2 melalui perencanaan, tindakan, observasi, dan refleksi, sedangkan instrumen yang dibutuhkan yakni test dan nontest, model analisis data adalah kualitatif dan kuantitatif. Hasil penelitian terbukti bahwa kemampuan siswa menulis puisi karya sastra menggunakan teknik inkuiri, latihan dan bimbingan untuk siswa kelas VIII-A SMPN 1 Rancabali, Alamendah, Kecamatan Rancabali, Kabupaten Bandung, pada siklus 1 dan 2 mengalami peningkatan belajar dan mengubah perilaku siswa terhadap minat menulis yang cukup signifikan.

Kata kunci; menulis puisi, inkuiri, dan pelatihan bimbingan

\section{PENDAHULUAN}

Belum tercapainya kemampuan menulis sastra puisi pada siswa, yakni masih minim siswa dalam menerima ilmu pengetahuan bahasa dan sastra Indonesia, karena mata pelajaran ini masih bersifat umum, sehingga kurang diapresiasi siswa. Padahal kemampuan menulis sastra puisi siswa dapat dibangun dengan baik, jika tujuan pembelajaran bahasa tersebut dapat dimanfaatkan secara maksimal, dalam mengembangkan budaya bahasa dan sastra sebagai karya luhur, karakter budi perkerti, dan wawasan pengetahuan siswa terhadap sastra puisi.

Menurut Aminuddin (2002:134) sastra puisi dapat membuat perbuatan atau karakter siswa menjadi baik. Pada dasarnya menciptakan suatu dunia tersendiri melalui berbagai narasi pesan moral atau ilustrasi tertentu, baik fisik maupun batiniah. Menurut Aftarudin (1993), puisi memiliki kualitas tersendiri dalam kehidupan manusia. Baribin (1990) mengatakan, sastra dalam puisi adalah bagian dari perilaku yang dapat diterjemahkan melalui narasi puisi. Puisi adalah ucapan yang mencerminkan melalui prosa ucapan 
langsung. Artinya, dengan puisi dapat membangkitkan emosional dengan penggambaran melalui bahasa figurasi.

Menurut Pradopo (2010;7) definisi puisi mengandung beberapa unsur antara lain, emosi, imajinasi, pemikiran, ide, nada, irama, kesan pancaindra, susunan kata, kata-kata kiasan, kepadatan, dan perasaan yang bercampur-baur. Hans Bague Jassin (1988) mengatakan, bahwa puisi adalah ungkapan perasaan. Penekanan perasaan di dalamnya. Penghayatan kehidupan manusia dan lingkungan, dimana puisi dibuat dan terlepas dari proses berpikir penyair.

Karya sastra memiliki her-meuneutik ambigu, sebab itu dibutuhkan pemaknaan yang lebih luas. Aritnya, jika hermeuneutik ambigu tersebut, ajarkan langsung kepada siswa, maka akan memiliki arti berbedabeda. Sebab itu, siswa semestinya diberikan pemahaman cukup dalam memaknai puisi orang.

Merujuk pada pengertian puisi dikatakan Tarigan (1993;2), Suharianto (2009;2), Jabrohim $(2003 ; 2$. dam Waluto $(2003 ; 1)$ bahwa puisi adalah bermakna yang didalam-Nya mengandung, ide, pikiran, gagasan, dari setiap pujangga yang tersusun rapi dengan ekspektasi makna tertentu.

Wiyanto (2005;34) mengatakan, dalam puisi ada beberapa unsur penting yakni; 1 ). kesesuaian isi dengan tema, 2). DIKSI, 3) Tema, diksi, dan 4). tipografi. Menurut Roestiyah (2008;75-76) bahwa model inkuiri adalah model yang digunakan guru kelas dalam memberikan pengajaran kepada siswa dalam kelas. Melalui model ini setiap guru kelas sewaktu dalam mengaja dalam benaknya harus terfokus pada tujuan akhir dari pembelajaran model ini sehingga siswa memahami dan mengerti dari tujuan pengajaran tersebut. Selain itu, membantu para siswa untuk terangsang dan termotivasi dalam belajar, aktif, dan teliti dalam menyingkap suatu masalah yang dihadapi.

Selain itu, model inkuiri memiliki keunggulan dalam pembelajaran di dalam kelas, antara lain adalah;

a) Membentuk dan mengembang-kan "sel-consept" pada diri siswa, serta paham terhadap konsep dasar dan ideide yang lebih baik.

b) Mengasah ingatan dan transfer pada situasi dalam proses pembelajaran siswa ketika di dalam kelas dan pada media baru yang mereka kenal.

c) Memotivasi siswa berpikir kritis dan bekerja keras atas inisiatif yang objektif, jujur, dan terbuka.

d) Mendorong siswa berpikir intuitif, merumuskan dan hipotesisnya sendiri.

e) Kepuasan bersifat intrinsik.

f) Situasi lebih merangkan belajar.

g) Pengembangan bakat siswa atau kecakapan individu.

h) Kebebasan siswa untuk mengajar mandiri.

i) Pembelajaran siswa ke arah lebih moder.

j) Membangun asimilasi dan mengakomodir informasi.

Model inkuiri dalam pembela-jaran siswa pada dasarnya sangat baik untuk pengembangan daya nalar siswa, dan mampu melihat kondisi secara realitas dalam lingkungan sekolah dan masyarakat sekitar. Sebab itu, siswa dilatih untuk lebih peka dan terangsang dalam belajar dan mampu mengekspresikan dirinya dalam belajar dengan semangat tak pernah kendor. Karena dalam proses pembelajaran tidak hanya dilakukan di dalam kelas namun di luar kelas pun diajarkan, sehingga mampu beradaptasi dengan kondisi lingkungan yang sebenarnya.

Sastra puisi memiliki tujuan yang hendak dicapai dan penting dalam meningkatkan 
kemampuan sastra dan puisi. Dalam konteks pendidikan, maka peran lembaga pendidikan memegang peran strategis sehingga setiap siswa dapat menguasai bahasanya sendiri secara baik. Hal ini sejalan dengan rujukan dari standar kompetensi dalam pelajaran bahasa Indonesia 4 bagian di antaranya, membaca, menulis, mendengar, dan bicara.

Dalam konteks ini, Waluyo (1991;25) mengatakan, bahwa puisi merupakan bentuk karya sastra yang dapat mengungkapkan perasaan, pikiran, gagasan dari manusia atau di penyair yang imajinatif. Dalam bentuk kalimat yang menguntai kosa kata sehingga menjadi indah dan hidup.

Minderop (2005) menuturkan, puisi adalah bagian dari sastra yang dengan kata-kata sebagai alat untuk menyampaikan sebuah ilusi dan imajinasi. Hal berbeda dikatakan Sapardi (dikutip Jabrohim, 2003;3) bahwa puisi suatu yang unik dari seorang penyair. Tentu saja tidak dengan mudah dicapai oleh seorang penyair hanya dengan asal-asalan, tanpa adanya perjuangan dalam pembelajaran bahasa dan satra puisi. Dengan perjuangannya, maka dia mampu mengolah kosa-kosa kata menjadi sesuatu yang indah dan bermakna. Sehingga semua orang sanggup memahami-Nya bahwa adanya makna terdalam pada sebuah puisi tersebut. Sebab itu, Supardi menilai bahwa tugas seorang pujangga yang berat adalah bagaimana setiap kosa kata tersebut menjadi sebuah makna yang dapat dipahami oleh semua orang dan informasi yang terkandung di dalamnya dapat tersampaikan dengan tepat ke publik.

Argumentasi lain, seperti diutarakan Waluyo $(2005 ; 1)$ bahwa puisi merupakan suatu karya sastra yang terindah. Puisi adalah perpaduan antara irama, bunyi, kata, dan emosi yang dipadukan sehingga menjadi hidup dan bermakna. Inilah bedanya puisi yang dapat memaknai realitas kehidupan.

Ilustrasi yang diberikan Pradopo $(2007 ; 8)$ mengatakan, suatu ide dan pemikiran dalam puisi dapat membangkitkan emosi dan perasaan yang merupakan hasil dari imajinasi pemikiran seorang penyair, atas susunan kalimat dari rangkaian kosa-kosa kata menjadi indah dan bermakna. Pada arti lain, bahwa puisi adalah gambaran dari interprestasi pengalaman manusia yang diwujudkan dalam bingkai puisi sehingga menjadi bermakna dalam arti kehidupan.

Komentar dari Komaidi $(2000 ; 202)$ puisi ialah suatu genre atau sejenis sastra atau sering kita samakan dengan sajak. Padahal keduanya berbeda antara puisi dengan sajak. Puisi yaitu jenis sastra yang melingkupi saja, sementara sajak adalah bagi individu dari puisi. Lebih jauh lagi, puisi adalah bentuk pendalaman dari seni sastra.

Penyair dalam menulis puisi mengacak kata-kata yang belum terpikirkan oleh orang lain, misalnya saja dalam memilih kata yang simetris, seimbang antara makna satu dengan lainnya sehingga memiliki korelasi kata yang sangat erat.

Semua statement para ahli di atas, dapat dijelaskan bahwa menulis puisi merupakan wujud nyata dalam bentuk komunikasi tidak langsung yang mengandung emosi, gagasan, ide, dan ekspresi seseorang. Sebab itu, dalam keterampilan dan kemampuan menulis sastra puisi, tidak lepas dari dari teknik-teknik menulis dengan baik. Model dan prinsip dalam penulisan seperti licentia poetica dalam penulisan puisi perlu diperhatikan, hal ini bertujuan agar puisi yang cipta banar-benar alami atau natural, dan sebagai wujud ekspresi diri secara bebas.

Teknik menulis sastra puisi secara monoton dapat dipastikan hasil yang di dapat tidak akan menarik publik, karena kosa kata yang 
terpilih tidak terkaji dengan baik dan menghasilkan karya yang kurang baik pula. Berbeda dengan puisi yang dibuat secara penuh kesungguhan dengan keilmuan yang cukup, maka makna dari isi puisi tentu akan penuh arti yang berbeda. Materi yang termuat juga penuh ekspresi dan aktualisasi diri yang bergagasan, ide-ide dan pemikiran berkualitas.

Demikian pula, apa yang diharapkan untuk para siswa di sekolah, khususnya bagi anak didik di jenjang pendidikan sekolah menengah pertama. Untuk mencapai tujuan tersebut, maka setiap siswa membutuhkan motivasi agar keter-tarikan terhadap bahasa dan sastra Indonesia semakin tinggi. Namun, menulis sastra puisi yang selama ini diperoleh dalam kelas sangat terbatas dan bersifat teoritis, sehingga membosankan siswa. Padahal dibutuhkan praktik secara langsung.

Untaian kata-kata sastra dalam puisi adalah suatu pembelajaran yang tidak boleh disepelekan. Makna penting yang terkandung dalam sastra puisi, jika ditempatkan pada edukatif yang konstruktif dengan apresiasi yang baik, maka sastra puisi tersebut dapat membantu siswa dalam pengembangan kreativitas, daya nalar, membangun karakter, dan menghargai karya sastra puisi orang lain.

Karya sastra puisi memiliki nilai-nilai pembelajaran yang baik termasuk dalam menulis sastra puisi untuk siswa dapat diajarkan secara kontemplasi. Artinya, mengajarkan untuk mengolah daya nalar siswa melalui olah kosa kata yang dapat diuraikan, kemudian menjadi satu kalimat bermakna bagi dirinya maupun orang lain.

Pembelajaran sastra puisi, maka materi yang harus diberikan terhadap pada siswa khususnya di SMP tidak lepas dari konteks untuk mengenal, meng-hayati, memahami, kepribadian, sikap, wawasan dan pengetahuan serta komunikasi sastra. Hal ini berbanding lurus dengan sikap kehidupan siswa agar kedepan dapat memiliki ilmu pengetahuan yang luas dan berkepribadian.

Melihat kondisi di lapangan saat ini, pada mata pelajaran bahasa dan sastra Indonesia kurang begitu optimal, sehingga hasil yang di dapat selama ini kurang menggembirakan. Kondisi ini pun cukup memprihatinkan karena apresiasi siswa terhadap sastra dan bahasa masih rendah sehingga aktualisasi terhadap sastra puisi tergolong rendah.

Pelaksanaan mata pelajaran sastra dan bahasa termasuk menulis sastra puisi belum berjalan dengan baik, kenyataannya pembelajaran menulis sastra puisi belum dilakukan secara maksimal dalam kelas khususnya terhadap siswa di kelas VIII.

Kendala yang muncul saat ini adalah pembelajaran menulis sastra puisi, bekum didukung oleh ketersediaan waktu ajar dalam kelas, minimnya sarna dan prasarana, minas siswa masih rendah, dan mata pelajaran bahasa dan sastra Indonesia dilakukan pada paruh waktu terakhir, sehingga energi siswa hanya sisanya atas pelajaran lain. Padahal seharusnya mata pelajaran bahasa dan sastra adalah prioritas yang perlu ditempatkan pada awal pelajaran mana pun.

Standar kompetensi kemandirian (SKK) siswa, di dalamnya mencakup sepuluh aspek perkembangan individu (SD dan SLTP) yang bertujuan agar siswa memiliki kemampuan berbahasa yang baik. Sebab itu, dengan kekurangan kemampuan dalam menulis sastra puisi akan berdampak pada pembelajaran lainnya, karena dalam pemahaman mata pelajaran bahasa dan sastra membutuhkan keseriusan sehingga tidak menjadi gagal paham pada materi bahasa dan sastra Indonesia, sebagai ciri dan bahasa utama bangsa ini. 
Permasalahan dalam penelitian ini, adalah bagaimana membangun kemampuan siswa dalam menulis bahasa dan sastra Indonesia pada aspek penulisan puisi dengan menggunakan model inkuiri dan latihan bimbingan untuk siswa kelas VIII-A SMPN 1 Rancabali, Alamendah, Kecamatan Rancabali, Kabupaten Bandung, Jawa Barat?

Tujuan dalam penelitian tersebut, guna mengetahui membangun kemampuan siswa dalam menulis bahasa dan sastra Indonesia pada aspek penulisan puisi dengan menggunakan model inkuiri dan latihan bimbingan untuk siswa kelas VIII-A SMPN 1 Rancabali, Alamendah, Kecamatan Rancabali, Kabupaten Bandung, Jawa Barat.

Hipotesis dalam kajian ini setelah mengikuti pembelajaran kemampuan menulis sastra puisi dengan menggunakan model inkuiri dan latihan bimbingan kemampuan menulis sastra puisi bagi siswa kelas VIII-A SMPN 1 Rancabali, meningkat dan terdorong belajar siswa kearah perubahan belajar modern yang positif.

\section{METODE PENELITIAN}

Desain kajian ini menganut model PTK (Penelitian Tindakan Kelas). Prosedur kerja penelitian PTK terbagi dalam empat komponen dasar, yakni; planning, acting, observing, reflecting (Riel, 2007). Proses implementasi penelitian ini diterapkan dengan dua tindakan siklus yakni siklus I dan siklus. Keduanya terdiri atas planning, acting, observing, reflecting. Subjek dalam kajian, yakni kemampuan menulis sastra puisi untuk siswa kelas VIII-A SMPN 1 Rancabali, Alamendah, Kecamatan Rancabali, Kabupaten Bandung, Jawa Barat. Penelitian kemampuan menulis sastra puisi menggunakan teknik inkuiri dan latihan bimbingan. Teknik pengumpulan data dengan cara test dan nontest. Pada teknik test, setiap siswa ditugaskan untuk menulis sastra puisi dengan teknik inkuiri, dan latihan bimbingan, yaitu dilakukan untuk pilihan kosa dan struktur kata tepat sesuai tema, isi, rima, dan tipografi. Kemudian data di analisis peneliti dengan menggunakan inkuiri teknik dan latihan bimbingan, setelah itu dideskripsikan secara kuantitatif dan kualitatif.

\section{HASIL DAN PEMBAHASAN}

Hasil pembahasan dalam kajian atau penelitian tindakan kelas (PTK) pada siklus I dan II terhadap kemampuan penulis sastra ke dalam bentuk puisi dengan model inkuiri dan latihan bimbingan, diperoleh nilai dari nontest yang deskripsikan antara lain, adanya ketekunan dalam belajar, sikap keterbukaan, kerajinan, disiplin, tenggang rasa antar sesama, patuh pada guru, kerja sama, ramah pada teman, kejujuran, komitmen, kepedulian, menepati janji dan tang-gung jawab. Semua data tersebut, diperoleh peneliti dengan instrument nontest, yakni observasi, interview atau wawancara, dan kajian pustaka atau dokumentasi.

Pembelajaran kemampuan menulis sastra puisi siswa dengan model inkuiri dan latihan bimbingan dalam pengajaran telah selaras dengan rencana pelaksanaan pembelajaran (lesson plan)/RPP. Dalam implementasi pengajaran siswa mengikutinya secara baik. Namun dengan berjalannya waktu, belum menampakkan hasil memuaskan sebagaimana diharapkan oleh guru dan sekolah. Namun masih ada siswa yang belum serius untuk mengikuti kemampuan menulis (write) sastra puisi. Tetapi tidak sedikit pula siswa yang antusiasme untuk mengikuti pengajaran 
dari guru. Hasil dari penilaian ada beberapa siswa yang memperoleh nilai sangat baik, setelah dilakukan dengan model inkuiri dan latihan bimbingan, meski secara rata-rata nilai masuk dalam kategori cukup.

Perubahan perilaku siswa terhadap pembelajaran kemampuan menulis sastra puisi mulai dampak positif. Sebagian besar siswa yang awalnya tidak tertarik, kini mulai bergeser pada minat mereka untuk belajar berkemampuan menulis sastra puisi. Ini terbukti adanya antusiasme besar para siswa untuk mengikuti pendidikan kemampuan menulis/write puisi melalui model inkuiri dan latihan bimbingan. Antusiasme lain, terlihat ketika siswa mengikuti pembelajaran tersebut, cukup serius. Dari pengamatan peneliti, mulai terbangunnya pembelajaran seperti adanya kerja sama dan disiplin yang secara langsung membatu siswa pada objek pembelajaran untuk dapat menemu-kan diksi sebagai dasar penulisan sebuah sastra. Hasil test yang dilakukan terkumpul data pada siklus I, dengan skor mencapai 66,81 dan ini dapat dikategorikan cukup. Hasil nilai tersebut, belum masuk pada kriteria yang telah ditentukan sekolah atau Kriteria Ketuntasan Minimal (KKM) yakni, 70,00 atau masuk kategori baik. Skor rata-rata pada aspek menulis sastra puisi dengan keselarasan isi dengan tema diperoleh sebesar 89,67, hal ini sangat baik. Sedangkan pada Diksi mencapai 69,2 berkategori cukup. Pada aspek Rima memiliki skor 50,0 hal ini berkategori kurang. Aspek Tipografi bernilai sebesar 57,43 juga masih dalam kategori kurang. Dari data yang diperoleh pada siklus I terlihat belum menunjukkan data maksimal yakni masih banyak kekurangannya. Artinya, masih ada di antara siswa yang kesulitan dalam menemukan diksi ketika memulai menulis kota kata sastra puisi, selain kekurangan pengetahuan juga belum didukung oleh suasana kelas yang kondusif karena terganggu oleh perilaku siswa yang belum fokus sehingga kelas menjadi gaduh. Perubahan perilaku terjadi setelah siswa mengikuti pembelajaran menulis sastra puisi dengan model inkuiri dan latihan bimbingan, nampak hasil yang muncul terlihat pada nontest siklus I, cukup signifikan hasilnya. Siklus I pada aspek keterbukaan terhadap guru dinilai baik, dan ini terdapat 20 siswa atau $(65,53 \%)$. Pada aspek tekun dan rajin belajar ada 17 orang siswa atau $(63,07 \%)$ masuk kategori cukup baik. Sedangkan 25 orang $(86,20 \%)$ pada aspek kerja sama dan peduli teman, sangat baik. Sementara ada 26 siswa $(88,64 \%)$ pada aspek ramah pada temah, sangat baik. Tetapi ada 11 orang anak $(36,92 \%)$ pada kepatuhan terhadap guru masih kurang, dan 24 orang anak $(82,74 \%)$ pada aspek kejujuran, sangat baik. Sekitar 29 siswa (100\%) secara konsisten, pada janji dan tanggung jawab pada kategori baik sekali. Pada siklus II pembelajaran kemampuan terhadap menulis sastra puisi dengan model inkuiri dan latihan bimbingan, nampak telah lebih baik. Dalam siklus II siswa lebih berdisiplin, patuh pada guru kelas, semangat, dan antusiasme saat diberikan arahan dan bimbingan oleh guru ajar dengan materi pengajaran. Selain itu, kondisi kelas semakin kondusif saat proses pembelajaran berlangsung. Yang lebih kentara lagu, yakni proses pembelajaran dua arah yang sebelumnya siswa terlihat pasif, namun pada segmen II ini siswa lebih produktif. Setiap siswa lebih terbuka dan tidak malu untuk bertanya, meski masih ada di antara siswa yang malu-malu.

Dalam segmen ini, kegiatan keterampilan kemampuan menulis sastra puisi siswa mulai terbangun dengan baik dan siswa mampu menyelesaikan tugas tersebut, secara baik dan tanggung jawab. Dan hasilnya setiap siswa dapat menampilkan 
hasil karya mereka di depan kelas untuk membacakan puisinya dengan penuh semangat. Dengan demikian, hasil yang di dapat cukup signifikan dengan menggunakan teknik dan latihan bimbingan dan lebih baik dari siklus pertama.

Hasil test siklus II hasilnya cukup signifikan yakni 66,76 atau $(45,84 \%)$. Pencapaian nilai rata-rata siklus II naik menjadi 17,12 atau (26,77\%). Artinya, siswa telah mencapai hasil yang memuaskan. Sementara hasil diperoleh dari keselarasan isi dengan Tema ketuntasan diperoleh $(89,67 \%)$ dan meningkatkan menjadi $(9,33 \%)$ menjadi $(100 \%)$ pada siklus II. Sementara, ketuntasan bernilai $(57,65 \%)$ meningkat jadi $(94,12 \%)$ pada siklus II. Sedangkan pada aspek Rima, ketuntasan sebesar $(42,35 \%)$ naik menjadi $(79,32 \%)$ pada siklus II, dan untuk Tipografi ketuntasan dari $(75,78 \%)$ naik jadi $(88,25 \%)$ pada siklus II.

Dari sisi psikologi dimana terjadi perubahan perilaku siswa untuk belajar kearah positif. Data yang diperoleh menunjukkan perubahan perilaku belajar, terutama pada keterbukaan sebesar $(62,51 \%)$ menjadi $(78,56 \%)$ pada siklus II. Ketekunan Belajar $(64,08 \%)$ naik menjadi $(78,35 \%)$ pada siklus II. Kerajinan belajar $(62,08 \%)$ naik menjadi $(75,68 \%)$ pada siklus II. Tenggang rasa pada teman dari $* 43,39 \%)$ naik menjadi $(69,98 \%)$ pada siklus II. Disiplin dari $(52,76 \%)$ naik jadi $(69,88 \%)$ pada siklus II. Aspek kerja sama mengalami peningkatan kejujuran mengalami peningkatan dari $(82,77 \%)$ naik menjadi $(89,65 \%)$ pada siklus II. Ramah pada teman, menepati janji dan tanggung jawab dari $(89,65 \%)$ menjadi (100\%). Kepedulian dari $(82,76 \%)$ menjadi $(86,21 \%)$ pada siklus II.

\section{SIMPULAN}

Dari hasil pembahasan PTK dapat disimpulkan bahwa dalam proses pembelajaran kemampuan menulis/write siswa dengan model inkuiri dan latihan bimbingan untuk kelas VIII-A SMPN 1 Rancabali, Alamendah, Kecamatan Rancabali, Kabupaten Bandung, dan sesuai dengan RPP. Pada tingkat kemam-puan menulis bahasa dan sastra puisi dengan model inkuiri dan latihan bimbingan mengalami peningkatan. Sikap perilaku siswa selama mengikuti pembelajaran kemampuan menulis sastra puisi mengalami perubahan positif dari siklus I hingga siklus II. Secara keseluruhan selama proses pembelajaran dapat terbangun kondisi belajar yang menyenangkan, menarik, lugas, jelas, kondusif, dan media pembelajaran yang digunakan mampu membuat antusiasme siswa. Berdasarkan hasil penelitian disaran-kan bahwa, guru pengampuh mata pelajaran bahasa dan sastra Indonesia dari hasil penelitian disarankan untuk menggunakan model inkuiri dan latihan bimbingan dalam memotivasi siswa dalam mengembangkan minat menulis sastra puisi. Hal itu terbukti mampu menumbuhkan cara berpikir aktif peserta didik melalui pengajaran model inkuiri dan latihan bimbingan.

\section{UCAPAN TERIMA KASIH}

Ucapan terima kasih kepada rekan-rekan yang telah membantu dalam penelitian ini hingga dapat selesai dengan baik. Khususnya pada rekan-rekan pada Dispendikbud Kabupaten Bandung, yang telah memberikan dukungan penuh dalam penelitian ini, dan kepada seluruh civitas akademika FKIP Unpas Bandung, terima kasih atas dukungannya dalam membantu menyelesaikan penelitian ini. Tidak lupa kepada kawan-kawan sejawat, terima kasih 
atas sumbangan gagasan dan kontribusi pemikirannya dalam penelitian ini.

\section{DAFTAR PUSTAKA}

Aminuddin. 2002. Pengantar Apresiasi Karya Sastra. Bandung: Sinar

Aftarudin, Didik. 1983. Pengantar Apresiasi Puisi. Bandung: Angkasa.

, Sabarti.dkk. 1991. Bahasa Indonesia II. Jakarta: Depdikbud.

Baribin, Raminah. 1990. Teori dan Apresiaisi Puisi. Semarang : IKIP Semarang Press.

Jabrohim. 2003. Cara Menulis Kreatif. Yogyakarta: Pustaka Pelajar.

Jassin, H. B. (ed.), 1995. Kontroversi Alquran Berwajah Puisi H. B. Jassin Penyusun, Jakarta: Pustaka Utama Grafiti, 1995. , 1991. Alquranul Karim Bacaan Mulia, Jakarta: Djambatan, 1991.

Komaidi, Didik. 2002. Aku Bisa Menulis. Yogyakarta: Sabda Media Pustaka Utama.

Kosasih. E. 2003. Ketatabahasaan dan Kesusastraan. Bandung: CV Yrama Widya.

Minderop, Albertine. 2005. Metode Karakteristik Telaah Fiksi. Jakarta: Yayasan Obor Indonesia

Pradopo, Rahmat Djoko. 2014. Pengkajian Puisi Analisis StrataNorma dan Analisis Struktural dan Semiotik. Yogyakarta: UGM Press.

Roestiyah, 2008. Strategi belajar mengajar, Jakarta Rineka Cipta.

Suharianto, 2009. Pengantar Apresiasi

Puisi. Surakarta, Widya Duta.
Tjahyono. 1988. Sastra Indonesia, Pengantar Teori dan Aplikasinya. Ende. Penerbit : Nusa Indah.

Tarigan, Henry Guntur, 1993. Menulis sebagai suatu keterampilan berbasan suatu keteramplan berbahasa, Bandung, Angkasa.

Waluyo, J. Herman, 2005. Teori dan Apresiasi Puisi, Jakarta, Erlangga.

Wiyanti Asul, 2005. Kesusastraan Sekolah. Jakarta: Grasindo. 